University for Business and Technology in Kosovo

UBT Knowledge Center

Oct 28th, 9:00 AM - Oct 30th, 5:00 PM

\title{
Risk assessment in the implementation of construction projects in developing countries
}

\section{Bashkim Alili}

Ss. Cyril and Methodius University, bashkim.alili@gmail.com

Follow this and additional works at: https://knowledgecenter.ubt-uni.net/conference

Part of the Architecture Commons

\section{Recommended Citation}

Alili, Bashkim, "Risk assessment in the implementation of construction projects in developing countries" (2016). UBT International Conference. 73.

https://knowledgecenter.ubt-uni.net/conference/2016/all-events/73

This Event is brought to you for free and open access by the Publication and Journals at UBT Knowledge Center. It has been accepted for inclusion in UBT International Conference by an authorized administrator of UBT Knowledge Center. For more information, please contact knowledge.center@ubt-uni.net. 
Book of Proceedings

International Conference on Architecture and Spatial Planning

\title{
Risk assessment in the implementation of construction projects in developing countries
}

\author{
Bashkim Alili \\ Institute of Earthquake Engineering and Engineering Seismology \\ "Ss. Cyril and Methodius "Skopje \\ bashkim.alili@gmail.com
}

\begin{abstract}
The construction industry plays an important role in the economic growth and the socioeconomic development, which are particularly important for the developing countries. The current general situation in the construction of buildings in a country like ours is that the product of a construction company is mainly characterized by the poor quality of work, exceeding the costs and the time for realization. These characteristics exist as many risks are taken into account very little in the project planning and realization or not taken into account at all. Therefore, it is necessary that the managing of the risks for improvement of the weak performances of the current project to be in the focus.

This paper aims to identify the main risk factors, that have a significant impact on the project realization, a framework model to be developed for risk management which includes identification, assessment, analysis, mitigation and risk control in order to achieve better performance and successful project implementation in a given time frame, and to minimize the exceeding of costs and to optimize the quality of the project.

The results obtained will affect the successful implementation of the project within the time frame, minimizing the excess of costs and optimization of the quality of the project.
\end{abstract}

Keywords: Construction, Developing Countries, Risk Assessment, Risk Management

\section{Introduction}

The construction project has been identified as one of the most dynamic, risky and complex undertakings [1] and [2], which in the developing countries is constantly facing difficulties in controlling the time and the costs which are almost always exceeding. The risk can be managed, minimized, shared, transferred or accepted. It cannot be ignored [3]. The risk management helps key stakeholders in the project - the customer, the contractor, the investor, the consultant or the supplier to meet their obligations and to minimize the negative impacts on the implementation of the project in terms of the cost, the time and the quality goals [4]. Risk management is a process which determines the activity of sources of the uncertainty (risk identification), evaluates the consequences of the uncertain events / conditions (risk analysis) and generates response of strategies [5].

In order to give response to this challenge, risk management has become an important part of the process of decision-making in the construction industry - as it determines the success or failure of the construction projects [6].

This paper's goal is to identify the main risk factors, that have a significant impact on the realisation of the project, and to develop a framework model for the risk management which includes identification, evaluation, analysis, mitigation and risk control in order to achieve better performance 
Risk assessment in the implementation of construction projects in developing countries

and successful project implementation in a given time frame, minimization of surpassing of the costs and to optimize the quality of the project.

\section{Review of literature}

\subsection{Risk during construction of the project}

Risk is a complex phenomenon with physical, monetary, cultural and social dimension. [7] Risk is the likelihood of occurrence of an uncertain, unpredictable and even adverse events that will change the possibilities for the profitability of a particular investment. [8]

The decision-making can be described with three methods, which include security, risk management and uncertainty [6]. Security exists only when it can be determined exactly what will happen during the time period covered by the decision and in accordance with the specific requirements of security [6]. The distinction between risk and uncertainty is needed in order to be able to explain the influence of these over the efficiency of project [9].

Therefore, the risk management in the construction project starts with the management of the uncertainty. This includes acquiring an understanding of the various sources of uncertainty, such as errors, inaccuracies, vagueness, variability, ignorance and ambiguity $[10,11]$.

\subsection{The process of risk management during implementation of construction projects}

Construction projects in the developing countries are constantly facing great difficulties in controlling and overpassing the time and the costs. A research shows that the efficiency of the construction in Macedonia is constant source of concern for the customers from the public and private sectors.

Williams [12] describes that the risks management of the project as an integrated process includes several activities for identification of uncertanty of the project, assessment of their impact, analyzis of their interactions, control during the execution phase and providing feedback to maintain collective assets .

Risk management is a business process that defines the sources of uncertainty (risk identification), assessment of the effects of uncertain events / conditions (risk analysis) and generate response strategies [13].

\subsection{Risk qualification}

Different approaches can be used to classify risks associated with construction projects and the explanation for the choice of method should serve the purpose of the study. In this paper, the risks will be grouped using the method Enshassi and Mosa [14] which classification of typical risk groups is a characteristic for the developing countries. Table 1 shows the different sets of risks. 
Table 1. Risk groups and risk factors in construction projects [14]

\begin{tabular}{|l|l|}
\hline Risk groups & Risk factors \\
\hline Physical risk & $\begin{array}{l}\text { Poor security procedures; Insufficient supplies of materials } \\
\text { Diverse workforce and productivity of equipment }\end{array}$ \\
\hline Risk of Environment & $\begin{array}{l}\text { Environmental factors (flood, earthquake, ... etc.) } \\
\text { Adverse weather conditions; inaccessibility }\end{array}$ \\
\hline Risk of design & $\begin{array}{l}\text { Defective and uncoordinated design; incorrect amounts } \\
\text { Inconsistency between quantities, drawings and specifications }\end{array}$ \\
\hline Risk of Logistics & $\begin{array}{l}\text { Unavailable labor, materials and equipment; High competition; } \\
\text { Inaccurate project program; Poor communication among team leaders }\end{array}$ \\
\hline Financial risk & $\begin{array}{l}\text { Inflation; Postponed payment; Financial failure of the contractor; } \\
\text { Fluctuation in exchange rate }\end{array}$ \\
\hline Legal risk & $\begin{array}{l}\text { Difficult to get a license; The ambiguity of laws; Legal disputes; } \\
\text { Postponed dispute resolution and more. }\end{array}$ \\
\hline Construction risk & $\begin{array}{l}\text { Gaps between implementation and specification; } \\
\text { Undocumented changes made; } \\
\text { The final amounts differ from the amounts of contract }\end{array}$ \\
\hline Political risk & $\begin{array}{l}\text { Segmentation of the building process; Handling of hazardous areas; } \\
\text { New governmental regulations or laws; Unstable security } \\
\text { circumstances }\end{array}$ \\
\hline
\end{tabular}

\subsection{Risk Assessment in construction projects}

The approaches that are commonly used in risk assessment in the construction of the project include: analysis of probability, tree analysis, sensitivity analysis, Monte Carlo simulation; Interval analysis assesses the credible range of results based on lines for variant input; Incoherent analysis is used to solve the problems of insecurity, particularly when probability information are limited and when the borders of volatility is not obvious [15].

Risk assessment is considered to be the most valuable part of the process of the risk management. Traditionally the focus was the quantitative risk analysis (16) despite the difficulties in obtaining fair probability in the construction industry (17). As a result, project managers must rely on subjective probability [18].

Mustafa and Al Bahar [19] adopted the Analytic Hierarchy Process (AHP) to assess the risk during the construction of the project. They applied the concept of value and weight for assessment of the probability of the risk and the impact.

Kangari [2] discusses the relationship of major US construction companies towards the risk and determines how much contractors conduct the risk management in building based on research of the great American contractors.

Oztas and Okmen [20] have presented a research literature on risk, management / risk analysis and system design - contract model, whereupon they propose model of risk analysis for costs deployment, which also shows the applicability of these models in determining the fixed estimation of price of the construction project through case study.

Zou et al [21] presented a new approach of the key risks of construction projects in China and developed strategies for managing them. Risks are prioritized according to their importance to the impact on typical objectives of the project in terms of the cost, the time, the quality, the safety and environmental sustainability, and then reviewed by a common perspective of the stakeholders in the project and the lifecycle.

Jaskowski and Biruk [22] propose a model for the assessment of the risk which is based on assessment and characteristics weight of a particular project and the expected conditions. Their method is to help the planners in determining the duration of the activities of parameters according to the level of risk. 
Risk assessment in the implementation of construction projects in developing countries

Their approach is in a combination with simulation techniques, for which it has been claimed that improves project planning and evaluation of alternatives for risk reduction.

After reviewing various contributions for assessment of the risk in construction sector, it is noted that the mentioned risk models can not accommodate the risks connected with construction projects in the developing countries, such as Macedonia, where cultural and political factors can influence the risk management of construction in the construction project. Therefore, a systematic model has been structured for improvement of the risk management in construction projects, as it is proposed to be the first step towards improvement of the process of risks management for project managers and entrepreneurs who work in the construction industry in the developing countries.

\section{Proposal framework for risks management in the construction industry in the developing countries}

The study proposes a mixed approach that includes a combination of both qualitative and quantitative methods for this research, in order to obtain data of all construction stakeholders.

\subsection{Design of research, methods and techniques}

A systematic approach toward the risk management of construction projects consists of the following main stages; identification of risk, assessment and analysis of risk, risk reduction and risks monitoring [23, 24, 25, 26; 27].

Therefore, in order to meet the objectives of research, research methodology, that consists of literature review, data collection (questionnaire, interviews and case studies), simulation and modeling, will be made to develop and check model of the risk management.

\subsection{Research approach}

\subsubsection{Review of literature}

This research starts with a rich literature in order to understand the concept of risk and risk management, including up to date the ongoing and the previous researches for evaluation and risk management in the construction sector.

\subsubsection{Data collection}

The data for the research will be collected through three methods: questionnaire, interviews and case research.

a) A questionnaire will be designed to review all the major risks in detail that are likely found in the construction projects in the developing countries.

b) Interviews are focused on customers, contractors, and other interested parties and it follows the format of open and closed questions.

c) Case study will target data acquisition from construction projects, which will be followed from the start to the end (the lifecycle approach) to observe all the risks that happen and their management by the participants of the project.

\subsubsection{Simulation of environment and a modeling of a building under construction}

Modeling and simulation can be described as a research process of behavior of the system in a simulated environment. Modeling may be based on computer or mathematical expressions. Usually, mathematical modeling aims to optimize or minimize the objective function. The task of the optimisation in risk management often seeks to identify the course of action which maximize or 
Book of Proceedings

International Conference on Architecture and Spatial Planning

minimizes the costs. However, an alternative of the mathematical representation of the decisions on risk management is a descriptive approach that provides insight into the project [22].

The seriousness of of the risk is determined by applying a degree of loss and probability of occurrence.

Risk $=($ level of loss $) \mathrm{x}$ (probability of occurrence).

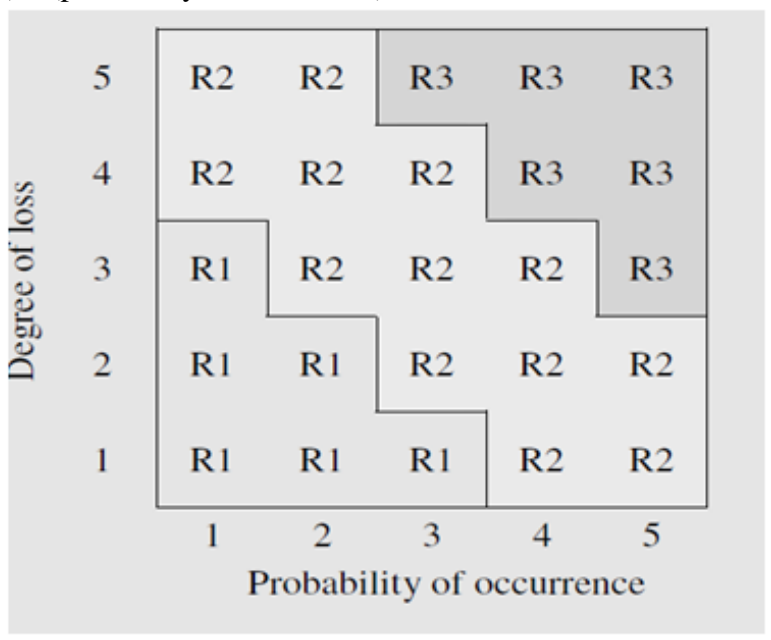

Low risk level: R1, High risk level: R3

\section{Development of a framework for risk assessment of construction projects}

The frame begins with identifying potential threats related to construction in construction projects, particularly in the developing countries.

Risk assessment will be done by giving priority to their threats according to the level of risks. This will be done in two main steps;

- The importance of risk - will be evaluated on the base of measuring the probability of occurrence of risk events and the impact of an accident caused by the event risk. This kind of matrix of risk is useful for the assessment of risk for categorization of the meaning in deadline of level "probability of influence".

- Assessment of the level of risk is done by determining the seriousness of the risk. The level of risk for each identified variable will be expressed in a synthetic way.

Analysis of changes of risks - will provide a contribution to the risk assessment for final quantification and formulation of the best strategic response. Typical inputs include the probability of occurrence of a risk factor, a factor of components, their relationships with potential effects, the seriousness of these effects and the difficulty in detecting them [64]. Monte Carlo simulation is an important tool for carrying out this risk analysis, in order to assess uncertainty and simultaneous consideration of the threats and opportunities, moreover, the probability of selecting different criteria [28]. The experimental simulation will be conducted by using MATLAB. The third phase of the framework will call for an effective strategy to reduce the effects of each identified risk and finally the ultimate goal of risk management is to deal with the risks which are common for construction projects in the developing countries, and thus achieving better control of the construction through the completion of 
Risk assessment in the implementation of construction projects in developing countries

the construction project. This will be done by monitoring every step and an effective communication between managers and other stakeholders in the project regarding the dangers that are threatening.

\section{Conclusions and the future of this study}

Construction projects are unique in terms of design, construction methods, staff, location and so on. The variations in these factors will cause different types of risk factors in the construction projects. Besides that, risk factors can come from many different directions, such as social, legal, economic, environmental, political, logistics, management and technological sources.

Therefore, within the framework of risk management can no longer accommodate risk factors that are specific for the developing countries, such as Macedonia, and that could influence the risk management of the construction projects. Hence, the development of a framework for risk management is undoubtedly necessary. This paper proposes a development of a system for risk assessment to improve the management of construction projects in the developing countries. It is based on a literature review and personal communication with experts and contractors from the construction sector. The existing models for assessing the risk, particularly in the construction sector, were also discussed on the basis of which conceptual framework has been developed. In the next stage, this study will include testing and validation of the framework of risk in the construction project, especially in the developing countries, with aim of identifying and evaluating of the typical risk factors affecting the completion of the project, and thus reducing their impact and the managing with them.

\section{References}

1. Lam E.W.M, Chan P.C.A, and Chan W.M.D., 2010, Qualitative survey on managing building maintenance projects; world academy of science, engineering and technology; Vol. 65, pp. 232-236.

2. Kangari R, 1995, Risk management perception and trend of US construction; Journal of construction Engineering and management; Vol. 121; No. 4; pp. 422-429.

3. Mills A, 2001, A systematic approach to risk management for construction; Structural survey, Vol. 19; No. 5; pp. 245-252.

4. John G.A, Clements-Croome D.J, Fairey V and Loy H.M., 2005, Contextual prerequisites for the application of ILS principles to the building services industry; Engineering construction and architectural management; Vol. 12; No. 4; pp. 307-338

5. Cavignac, J, 2009, Managing risk in a construction company. Construction business owner

6. Abujnah M and Eaton, 2010, Towards a risk management framework for Libyan housebuilding projects; the research institute for the building and human environment, University of Salford; pp. 346-353;

7. Loosemore M, Raftery J, Reilly C and Higgon D., 2006, Risk management in projects; 2nd edition, Taylor and Francis.

8. Kartam N.A and Kartam S.A., 2001, Risk and its management in Kuwaiti construction industry: a Contractor's perspective; International Journal of project management; vol. 19, pp. 325-335

9. Perminova O, Gustafsson and Wikstrom K., 2008, Defining uncertainty in projects- a new perspective; International Journal of Project Management; Vol. 26; pp. 73-79. 
10. Baloi, D. and Price, A.D.F, 2003, Modelling global risk factors affecting construction cost performance; International Journal of Project Management; vol. 21 no. 4; pp. 261-9.

11. Chapman C.B. and Ward S.C., 2003, Project risk management: processes; techniques and insights; 2nd edition; John Wiley \& Sons Ltd.

12. Williams, T, 1995, A classified bibliography of recent research relating to project risk management. European Journal of Operational Research, Vol. 85, pp. 18-38.

13. Zavadskas E.Z, Turskis $Z$ and Tamosaitiene J, 2010, Risk assessment of construction projects; Journal of civil engineering and management; Vol. 16; No. 1; pp. 33-46

14. Kuo Y and Lu S, 2013, Using fuzzy multiple criteria decision making approach to enhance risk assessment for metropolitan construction projects; international journal of project management; vol. 31; pp. 602-614.

15. Enshassi A and Mosa J A, 2008, Risk management in projects: Owners perspective; The Islamic University journal (Series of natural studies and engineering); vol. 16; No. 1; pp. 95123.

16. Carr V and Tah J, 2001, A Fuzzy Approach to Construction Project Risk Assessment and Analysis: construction project risk management system; Advances in Engineering Software; vol. 32; pp. 847-857.

17. Flanagan, R and Norman, G, 1993, Risk management and construction, Blackwell Publishing, Oxford, UK.

18. Winch, G. M, 2003, Managing Construction Projects: An information Processing Approach, Blackwell Publishing, Oxford, UK.

19. Mustafa, M.A and Al-Bahar, J.F, 1991, Project risk analytic assessment using the hierarchy process; IEEE Transaction on Engineering Management; vol. 38; No. 1; pp. 46-52.

20. Oztas A and Okmen O, 2004, Risk analysis in fixed-price design-build construction projects; Building and Environment; Vol. 39; pp. 229-237.

21. Zou P.X.W, Zhang G and Wang J, 2007, understanding the key risk in construction projects in China: International journal of project management; Vol. 25; pp. 601-614.

22. Smith, N. J, Merna, T and Jobling, P., 2006, Managing risk in construction projects, Blackwell Science, Oxford.

23. Jaskowski P and Biruk S, 2011, The conceptual framework for construction project risk assessment; Reliability: Theory and Application; Vol. 2, pp. 27-35.

24. Wysocki, R. K, 2009, Effective project management traditional, agile, extreme. Indianapolis: John Wiley and Sons.

25. Institute of Civil Engineers (ICE) and faculty and Institute of Actuaries (FIA), 2005, Risk analysis and management for project (RAMP); Thomas Telford, London.

26. Association for project management (APM), 2004, Project risk analysis and management (PRAM) guide; The APM group, UK.

27. Godfrey S.P, 1996, Control of Risk; A guide to the systematic management of risk from construction; construction industry research and information association (CIRIA); Sir William Halcrow and Partner Ltd, London;

28. Rezaie K, Amalnik M.S, Gereie A, Ostadi B and Shakseniaee, 2007, Using extended Monte Carlo simulation method for the improvement of risk management: consideration of relationships between uncertainties; applied mathematics and computation; vol. 190; pp. 14921501. 